\title{
Factors influencing Internet banking adoption in South African rural areas
}

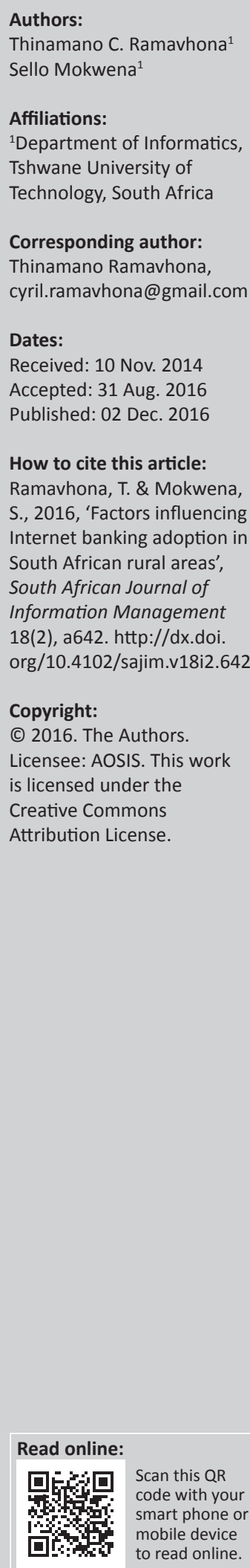

\begin{abstract}
Background: The banking industry globally provides Internet banking to offer their customers easy access to banking services. The banks in South Africa, like their counterparts in other parts of the world, offer Internet banking to customers. However, the majority of South Africans in rural areas do not adopt and use Internet banking despite its convenience, the availability of Internet banking infrastructure, the effort of banks in promoting Internet banking awareness and Internet security.
\end{abstract}

Objectives: This research investigated factors which influence the adoption and use of Internet banking in the context of South African rural areas.

Method: In this study, a quantitative research approach was used. Data were collected through questionnaires and analysed using Statistical Package for Social Sciences (SPSS) tool.

Results: The perceived compatibility, trialability and external variables such as awareness and security were found to have significant influence in the adoption of Internet banking in South African rural areas, whereas relative advantage was found not to be a significant factor. Security and the complexity of Internet banking were also revealed as some of the factors hampering the intention to adopt Internet banking in South African rural areas.

Conclusion: The lack of awareness on Internet banking services and its benefits such as its convenience and the possibility to conduct banking transactions from any location with Internet is found to be the reason for South African rural area retail bank consumers' reluctance to adopt Internet banking. The majority of retail bank customers in South African rural areas do not use Internet banking because of the lack of resources, such as computers with Internet access. The security of transactions conducted over the Internet is the main concern and significant element that customers consider before adopting Internet banking in South African rural areas as they perceive it as being easily exposed to fraud. As a result, this perception erodes retail bank customers' confidence to adopt Internet banking. The majority of retail bank customers in South African rural areas will be willing to adopt Internet banking if their lifestyle, values and specific need are met. Retail bank customers in South African rural areas will adopt Internet banking if the Internet banking processes are simplified and user-friendly.

\section{Introduction}

The banking industry worldwide provides Internet banking to offer customers easy access to banking services (Adapa 2011). Internet banking was first introduced around the early 1980s and started gaining momentum in developing countries in the mid-1990s (Peterson 2006). Internet banking has transformed the way banks conduct their business, and has expanded their consumer base, which includes rural areas (Gonzalez, Dentiste \& Rhonda 2008; Peterson 2006). Internet banking allows bank customers to transact on their accounts without physically visiting the banks by using the bank's software over the Internet (Zheng 2010). Internet banking customers access bank accounts from a remote location as long as there is Internet access (ABSA Bank 2011:1). The main benefit of Internet banking is that it is cheap and offers its users services that are convenient and not limited to time and place (Brogdon 1999:4; Wu 2005). Internet banking can be used to conduct banking transactions such as checking balances, transferring money and paying utility bills without physically visiting a branch (FNB 2011:2). Internet banking improves client safety by reducing the need to carry large amounts of cash (Wu 2005:13). The accessibility of Internet banking in rural areas is hindered by a number of factors which impede constructive use of Internet services (Cloete \& Ramburn 2006:4).

South Africa has four major banks: Amalgamated Banks of South Africa (ABSA), Standard Bank, Nedbank and First National Bank (FNB). ABSA Bank was the first to offer limited transactions online in late 1996 and was followed by Nedbank which offered full Internet 
services in early 1997. Standard Bank introduced Internet banking services in July 1997 and later FNB added its working sites to the web in August 1997 (Singh 2004:190).

In South Africa, about 22 million people, 38.3\% of the population reside in rural areas and $61.7 \%$ live in urban areas (Stats SA 2011). The rural population is not equally distributed over the provinces. Limpopo and KwaZulu-Natal provinces have the highest proportion of rural dwellers (Stats SA 2011). South African banks provide their rural customers with Internet banking in order to enable them to perform bank transactions through the bank's website without visiting a physical branch (Wang et al. 2003:22; Zheng, 2010). The Internet banking infrastructural distribution in South African rural areas is different from that in urban areas or other countries because of its demographic factors and Internet infrastructure (Green \& Van Belle 2002). Little research has been conducted on Internet banking in South Africa ( $\mathrm{Wu}$ 2005). The adoption of Internet banking by consumers in rural areas is lower than that of urban areas (Masocha et al. 2010), despite the benefits of Internet banking. There are still customers who prefer the traditional banking methods (Munusamy 2012).

\section{Background}

South Africans in rural areas are not adopting Internet banking despite the availability of Internet banking infrastructure and the efforts of banks in promoting Internet banking awareness, security and the convenience of the system. The aim of this study was to investigate factors that may influence the adoption and use of Internet banking in the context of South African rural areas. To conceptualise the theoretical and practical framework for the above stated problem, the following question guided the research: Why are South Africans in rural areas not adopting and using Internet banking despite the availability of Internet banking infrastructure and the effort of banks in promoting Internet banking awareness, security and the convenience of the system?

\section{Literature review}

\section{Internet banking}

Internet banking is described as the delivery of information or services by the banks to their customers using computers or mobile phones via the Internet (Daniel 1999:73). Internet banking is a banking service, which gives consumers a platform to perform banking functions online (Onay \& Ozsoz 2013; Ongkasuwan 2002:3). According to Kyobutungi (2014) and Wang et al. (2003), Internet banking allows users to undertake financial transactions without the need to physically visit the bank. Consumers' migration to Internet banking is boosted by the ability to conduct banking transactions $24 \mathrm{~h}$ a day, anywhere, faster and with lower cost compared to using traditional bank branches (ABSA Online 2015; Sayar \& Wolfe 2007). Redlinghuis and Rensleigh (2010) shared the same sentiment that convenience is one of the key factors for customers. This is reflected and supported in the study conducted by Yuan, Lee and Kim (2010), where it was found that the 'implementation of Internet banking eliminated the constraints associated with time and place'. Although customers in both rural and urban areas are expected to enjoy numerous benefits as a result of the implementation of Internet banking, there are various challenges that hamper the use of Internet banking services for rural customers.

\section{Challenges with Internet banking}

The limited access to computers and the Internet by South African public dwelling in rural areas is one of the serious inhibitors of information technology innovations in South Africa (April \& Cradock 2000). This has implications for the Internet banking industry. Lack of infrastructure in rural areas results in the public not being able to gain access to Internet banking services. Infrastructural inadequacy is a widespread challenge, particularly in the former homeland rural areas of South Africa such as Limpopo province (Kgantsi \& Mokoene 1997).

\section{Opportunities for Internet banking in rural settings}

There is telecommunication infrastructure to support Internet banking in rural areas. This infrastructure includes the use of mobile phones and personal computers (AFDB 2010).

Internet banking refers to the ways in which bank customers both in urban and rural areas can access their bank accounts via the bank's website through personal computers and mobile phones without being physically present at the bank's branch (Leow 1999).

Telecommunication and banking services have created opportunities for the emergence of mobile banking. Mobile banking services provide customers convenience together with cost savings. According to the International Telecommunication Union (ITU) report, 'there is a significant growth in the use of mobile phones, with mobile-cellular penetration rates stand at $96 \%$ globally; $128 \%$ in developed countries; and $89 \%$ in developing countries with South Africa included' (ITU 2013). Mobile phones can be used as Internet banking terminals. This will enable user access to financial services and provide fundamental services such as instant access to any bank account and the ability to make payments and transfers remotely (AFDB 2010).

The Wallis Report (1997) has indicated that the level of Internet banking security is the key factor in determining customers' decision in using Internet banking. The study conducted in Australia by O'Connell (1996) pointed out that security concern was the leading cause of the slow adoption of Internet banking in the country. Internet banking security is considered the main challenge by potential users when considering Internet banking in South African rural areas. South African banks offer clients security such as a personal identification number (PIN) in order to prevent unauthorised access to their accounts (Martins, Martins \& Olivier 2001:32), as well as one time pin (OTP) (which is a single, unique and 
time-sensitive PIN) used as added security on online banking. According to Pather (2007), the OTP has proved to be successful in preventing online fraud in the South African banking sector.

Cost is one of the key factors that stimulate the consumer adoption of innovation. It has been stated in Wallis Report (1997) that if consumers are to use new technologies, the technologies must be reasonably priced compared to their alternatives. A study conducted by Bareczal and Ellen (1997:137) indicates that consumers may be reluctant to adopt a new innovation, such as Internet banking, unless it reduces their costs and does not require them to change their behaviour when using it.

The consumers' adoption or rejection of a new innovation such as Internet banking starts when the consumer becomes aware of the innovation (Rogers \& Shoemaker 1971). Several studies have been conducted that empirically supported the idea that consumer knowledge and awareness had an effect on Internet banking adoption (Polatoglu \& Ekin 2001; Sathye 1999).

\section{Demographic features of Internet banking adopters}

Demography can be defined as a study of human population statistics which include size, age, sex, race, location, occupation, income and education (Loudon \& DellaBitta 1993:35). Each of these features influences the nature of consumers' needs and wants, and the ability to purchase products or services. South Africa has high inequality standard of living between urban and rural areas. The consumer demographic factors related to this study are age, education level, income and occupation. Most of the consumers who use Internet banking services are usually highly educated, with higher income and having better occupations than non-users (Karjaluoto 2002:359).

\section{Theoretical foundations}

Diffusion of innovation theory attempts to identify patterns and rates of adoption of innovation (Rogers 1995). There are five characteristics of innovations which influence individuals in the adoption of new innovation:

- Relative advantage, defined as an extent to which an innovation is perceived as being better than its previous innovation or existing counterparts, usually expressed in terms of economic and social benefits such as cost savings and convenience (Rogers 1995).

- Compatibility, which is defined as an extent to which an innovation is perceived as consistent with the existing values, past experiences and needs of potential adopters (Rogers 1983, 1995). It is measured in terms of how innovation fits into individual life situations.

- Complexity is defined as an extent to which the consumer considers the innovation to be difficult to use. It is measured in terms of innovations' levels of complexity experienced by potential adopters (Rogers 1995).

- According to Rogers (1983), 'triability contributes to achieving some sort of comfort among the customers and the users who may later become more willing to adopt this innovation'.

- Observability, which is the degree to which the results of an innovation are visible to others. In the context of this study, individuals normally do banking transactions privately; this transaction is not observable and visible to others because of security reasons (Tan \& Teo 2000), and therefore the observation element is removed from this study about Internet banking adoption in rural areas.

- Two external factors Awareness and Security have been added in this study, as they are also critical factors in the diffusion of innovations such as Internet banking.

- Security of Internet banking refers to the threat and risks of identity theft and fraud that the individuals are exposed to and the measures to safeguard Internet banking (Kalakota \& Whinston 1997).

Several researchers have applied diffusion of innovation theory. Moore and Benbasat (1991) applied it in their study of instrument development. Tan and Teo (2000), Taylor and Todd (1995) used it as a part of their research models. The individual characteristics, relative advantage, compatibility and complexity, together with the external factors awareness and security were critical in this study in a quest to identify factors influencing the adoption of Internet banking in South African rural areas.

\section{Research method and design Hypothesis of this research}

In this study, six hypotheses have been derived from the research questions and objective of this study.

The previous research study conducted by Sohail and Shanmugham (2003) on Internet banking has revealed that awareness of the benefits and advantages of Internet banking has an influence on the customer's adoption of Internet banking. This has been supported by other previous studies which indicated that the lack of awareness of Internet banking and its benefits was revealed as a reason for individuals' reluctance to adopt Internet banking (Sathye 1999). Hence, this study hypothesises that:

Hypothesis 1: Awareness of Internet banking positively affects the adoption and use of Internet banking in South African rural areas.

Gerrard and Cunningham (2003:8) recognise perceived relative advantage as an important factor influencing the adoption of Internet banking. Relative advantage is measured in terms of innovations' economic profitability, time saving, and decrease in discomfort and effort (Rogers 1983:217). This has been asserted by Agarwal and Prasad (1998:222) who have indicated that 'relative usefulness of an innovation is positively related to its rate of adoption'. Hence, this study hypothesises that:

Hypothesis 2: Relative advantage affects the intention to adopt and use Internet banking in South African rural areas. 
A number of previous researchers revealed that compatibility is one of the main factors that promote the diffusion of innovation to consumers. Compatibility leads to the rapid adoption of any new ideas or technologies. The study conducted by Kolodinsky, Hogarth and Hilgert (2004) identified compatibility as having a positively significant relationship with Internet banking adoption, while the study conducted by Gounaris and Koritos (2008) has found compatibility as insignificant to the adoption of Internet banking. Therefore, this study hypothesises that:

Hypothesis 3: Compatibility affects the adoption and use of Internet banking in South African rural areas.

Rogers (1983:230) has argued that the adoption of innovation will be less likely if it is perceived as being complex or difficult to use. In addition, $\mathrm{Wu}(2005)$ also indicated that the adoption of Internet banking is far more likely to occur if the Internet banking processes are simple and user-friendly. Hence, this study hypothesises that:

Hypothesis 4: Complexity affects the adoption and use of Internet banking in South African rural areas.

According to Tan and Teo (2000), 'if the user got the chance to try a new technology, this would lessen his feelings of fear concerning the usage of this technology'. In the previous study conducted by Hernandez and Mazoon (2007), trialability has been revealed as a significant factor in the adoption of Internet banking. This study also hypothesises trialability effect on Internet banking adoption as follows:

Hypothesis 5: Trialability of Internet banking positively influences the adoption of Internet banking in South African rural areas.

Sathye (1999) has indicated that the majority of users avoided Internet banking adoption because of the concern about security of transactions over the Internet. Several previous researchers showed that the issue of security is more critical in Internet banking adoption because transactions on Internet banking comprise sensitive information and individuals involved in the financial transaction are concerned about access by fraudsters to sensitive files and information transferred via the Internet (Alsajjan \& Dennis 2009; Suh \& Han 2002). Hence, this study hypothesises that:

Hypothesis 6: Internet banking security affects the intention to adopt and use Internet banking in South African rural areas.

\section{Research methodology}

This research aimed to identify the factors influencing the adoption of Internet banking in South African rural areas. The researcher adopted a cross-sectional approach during data collection. A sample size of 400 respondents was targeted. Data collection for this study was restricted to Limpopo province because it is one of the provinces with the highest proportion of rural dwellers (Stats SA 2011). A nonprobability sampling method was used. This sampling method relies on the personal judgement of the researcher rather than chance to select sample elements (Malhotra 1999:334; Mokwena 2011:142). A closed item self-administered questionnaire was used as a main method to collect responses from school teachers.

The five-point Likert scale was used in the questionnaire for statements that required scaling to determine Internet banking customers' perceptions and non-Internet banking customers' perceptions and attitudes. The researcher used strongly agree (SA), agree (A), uncertain (U), disagree (D) and strongly disagree (SD) codes throughout where statements required respondents to choose one of these options. A pilot survey was conducted. In the pre-pilot study, the questionnaire was administered to a small group of respondents who were retail bank customers (teachers) from four schools in rural areas of Limpopo province in order to determine whether the questions were understandable as well as to test whether survey procedures worked.

The survey questionnaire was pilot tested and reviewed before it was finalised. Permission from the Provincial Department of Education was secured to collect research data from teachers.

A total of 400 questionnaires were distributed by the researcher to 45 schools in the rural areas of Limpopo province of South Africa. Out of 201 (50.25\%) responses received, 41 (10.25\%) were not useable, and 159 (39.5\%) questionnaires were not returned. The study therefore used the remaining 160 responses that were useable. Data preparation, which includes coding, capturing and editing of the data, was conducted, and the data were captured using Microsoft Excel and then imported to SPSS 22 for analysis.

\section{Data analysis and results Description of respondents}

IBM SPSS 22 was used for analysis of the demographics of the collected data. The majority of respondents were males (55.6\%) and $44.4 \%$ were females. The majority of respondents were between the ages of 26 and 35 years (37.5\%), followed by $36-45$ years $(26.3 \%)$; the age group of $18-25$ years accounted for $18.8 \%$, while that of $46-55$ years accounted for $13.1 \%$ and over 56 years accounted for $4.4 \%$.

Of the respondents, $40.6 \%$ had diplomas, $29.4 \%$ had bachelor degrees, $11.9 \%$ had certificates and $9.4 \%$ had postgraduate degrees.

All the respondents were employed, with full-time employees accounting for $92.5 \%$ and part-timers or interns accounting for $7.5 \%$ of the respondents. The majority of respondents (66.9\%) earned an income of R4000 and above, followed by $15.6 \%$ of respondents earning between R3000 and R3999, 7.5\% respondents earning between R2000 and R2999, while $2.5 \%$ of the respondents earned between R0 and R1999. 


\section{Internet banking usage and experience of the respondents}

The majority of respondents (70.6\%) indicated that they have never used Internet banking, while $62.5 \%$ of respondents cited that they do not have computers with Internet access in order to access Internet banking and as a result preferred visiting bank branches physically. Only $27.5 \%$ respondents indicated that they were using or used Internet banking before.

\section{The relative advantages of Internet banking}

A total of $57.5 \%$ of respondents indicated that Internet banking makes it easier for them to conduct their banking transactions in rural areas, only $16.3 \%$ of respondents were uncertain, whereas $26.3 \%$ disagreed with the statements. Once again, more than $50 \%$ of respondents indicated that Internet banking gives them greater control in managing their finances more efficiently.

\section{The complexity of Internet banking}

The majority of respondents (40\%) indicated that they disagree that Internet banking programme makes it easy to manage their finances in rural areas, only $22.5 \%$ of respondents were uncertain, while $37.6 \%$ of respondents agreed that an Internet banking programme makes it easy to manage their finances in rural areas. While the majority of respondents (44.3\%) indicated that Internet banking process is simple, only 41.9 of respondents indicated that they were uncertain, while $13.8 \%$ disagreed with the statements. The majority of respondents $(37.7 \%)$ indicated that learning to use Internet banking is easy and only $25 \%$ of respondents indicated that they were uncertain about the statement, while $37.5 \%$ disagreed with the statements.

\section{The compatibility of Internet banking}

The majority of respondents (58.2\%) indicated that using Internet banking to do their banking business fits into their work style, only $14.4 \%$ of respondents were uncertain, while $27.6 \%$ disagreed with the statements. Once again, the majority of respondents (63.8\%) indicated that Internet banking is more convenient than queuing in the bank, and only $12.5 \%$ of respondents were uncertain, while $23.8 \%$ disagreed that Internet banking is more convenient than queuing in the bank branches. Of the respondents, $81.4 \%$ indicated that Internet banking could save them time and travelling costs in rural areas, only $16.2 \%$ of respondents were uncertain, while $2.4 \%$ disagreed that Internet banking could save them time and travelling cost.

\section{The trialability of Internet banking}

At least $63.8 \%$ of respondents indicated that they want to be able to try Internet banking for at least 1 month, while 33.6\% of respondents were uncertain. Other respondents did not want to try Internet banking. Once again, the majority of respondents $(62.5 \%)$ indicated that they want to be able to use Internet banking on a trial basis to see what it can do; only $13.8 \%$ of respondents indicated that they were uncertain, while $23.8 \%$ disagreed with the statements.

\section{The awareness of Internet banking}

The majority of respondents (58.8\%) indicated that they were aware of Internet banking and the facilities it offers; only $10.0 \%$ of respondents were uncertain, while $31.3 \%$ of respondents disagreed with the statements. Once again, $56.9 \%$ of respondents indicated that they were aware of what needs to be done in order to become an Internet banking user; only $16.3 \%$ of respondents were uncertain, while $26.9 \%$ of respondents disagreed with the statements. The majority of respondents (53.2\%) indicated that they were aware of the services that could be used through Internet banking, only $18.8 \%$ of respondents were uncertain, while $28.1 \%$ disagreed with the statements.

\section{Security on Internet banking}

The majority of respondents (56.9\%) disagreed that using Internet banking is as safe as visiting the bank branches physically, only $15.0 \%$ of respondents were uncertain, while $28.2 \%$ agreed that using Internet banking is as safe as visiting the bank branches physically. Once again, 50.7\% of respondents indicated that the banks offering Internet banking have not set security measures to protect their bank customers, only $19.4 \%$ of respondents were uncertain, while $30.0 \%$ of respondents disagreed with the statements.

\section{Intention to adopt Internet banking service}

The majority of respondents (61.9\%) indicated that they have intentions to use Internet banking service in the near future, only $11.9 \%$ of respondents were uncertain, while $26.2 \%$ indicated that they were not planning to use Internet banking service in the near future.

\section{Reliability test}

The reliability test was conducted using Cronbach's alphas to test all the constructs used in this study for internal consistency. The alpha value for the measures in this study has ranged from 0.724 to 0.956 , as reflected in Table 1 . All the constructs have Cronbach's alpha value of more than 0.7; therefore, no internal consistency problems were found in further statistical analysis in the study.

\section{Correlation analysis}

Pearson's correlation analysis was used to determine the relationship between different variables in the study, which included relative advantage, compatibility, complexity, trialability, awareness, security and adoption of Internet banking. The correlation in the study checked the directions and strength of relationships that exist among the study variables. See Table 2 for the correlation analysis results. 
TABLE 1: Reliability analysis using Cronbach's alpha.

\begin{tabular}{|c|c|c|c|c|}
\hline Item statistics & Indicator & Mean & SD & $\alpha$ \\
\hline \multirow[t]{3}{*}{ Relative advantage } & RELAD1 & 2.53 & 1.273 & \multirow{3}{*}{0.956} \\
\hline & RELAD2 & 2.67 & 1.242 & \\
\hline & RELAD3 & 2.66 & 1.253 & \\
\hline \multirow[t]{3}{*}{ Compatibility } & COMPA1 & 2.56 & 1.262 & \multirow{3}{*}{0.948} \\
\hline & COMPA2 & 2.36 & 1.210 & \\
\hline & СОМРАЗ & 2.28 & 1.202 & \\
\hline \multirow[t]{3}{*}{ Complexity } & COMPL1 & 2.95 & 1.179 & \multirow{3}{*}{0.918} \\
\hline & COMPL2 & 2.91 & 1.187 & \\
\hline & COMPL3 & 2.91 & 1.198 & \\
\hline \multirow[t]{3}{*}{ Trialability } & TRI1 & 2.39 & 1.279 & \multirow{3}{*}{0.724} \\
\hline & TRI2 & 2.44 & 1.282 & \\
\hline & TRI3 & 3.36 & 1.481 & \\
\hline Security & SEC1 & 3.31 & 1.245 & 0.838 \\
\hline \multirow[t]{3}{*}{ Awareness } & AW1 & 2.58 & 1.262 & \multirow{3}{*}{0.927} \\
\hline & AW2 & 2.52 & 1.239 & \\
\hline & AW3 & 2.56 & 1.222 & \\
\hline \multirow[t]{3}{*}{ Intention to adopt IB } & IB1 & 2.39 & 1.279 & \multirow{3}{*}{0.724} \\
\hline & IB2 & 2.44 & 1.282 & \\
\hline & IB3 & 3.36 & 1.481 & \\
\hline
\end{tabular}

Source: Ramavhona, T.C. \& Mokwena, S.N., 2014, Factors influencing internet banking adoption in South African rural areas, Master's dissertation, Tshwane University of Technology, Tshwane, viewed 09 November 2016, from http://encore.tut.ac.za/iii/cpro/DigitalltemViewPage.external?lang=eng\&sp=1001585\&sp=T\&suite=def

AW, awareness; COMPA, compatibility; COMPL, complexity; IB, Internet banking; RELAD, relative advantage; SD, standard deviation; SEC, security; TRI, trialability.

TABLE 2: Correlation analysis results in the study.

\begin{tabular}{|c|c|c|c|c|c|c|c|c|}
\hline Variables & & 1 & 2 & 3 & 4 & 5 & 6 & 7 \\
\hline Relative advantage & Pearson's correlation & 1 & - & - & - & - & - & - \\
\hline Compatibility & Pearson's correlation & $0.856^{*}$ & 1 & - & - & - & - & - \\
\hline Complexity & Pearson's correlation & $0.599 *$ & $0.619 *$ & 1 & - & - & - & - \\
\hline Trialability & Pearson's correlation & $0.636^{*}$ & $0.640 *$ & $0.612^{*}$ & 1 & - & - & - \\
\hline Awareness & Pearson's correlation & $0.551^{*}$ & $0.546^{*}$ & $0.534 *$ & $0.560 *$ & 1 & - & - \\
\hline Security & Pearson's correlation & $0.403 *$ & $0.416^{*}$ & $0.619 *$ & $0.476 *$ & $0.374 *$ & 1 & - \\
\hline Intention to banking adoption & Pearson's correlation & $0.658 *$ & $0.669 *$ & $0.534 *$ & $0.704 *$ & $0.607^{*}$ & $0.489 *$ & 1 \\
\hline
\end{tabular}

Source: Ramavhona, T.C. \& Mokwena, S.N., 2014, Factors influencing internet banking adoption in South African rural areas, Master's dissertation, Tshwane University of Technology, Tshwane, viewed 09 November 2016, from http://encore.tut.ac.za/iii/cpro/DigitalltemViewPage.external?lang=eng\&sp=1001585\&sp=T\&suite=def

*, Correlation is significant at the 0.01 level (2-tailed).

\section{Regression analysis}

Regression analysis was used to determine the degree to which relative advantage, complexity, compatibility, trialability, awareness and security influenced the adoption of Internet banking in South African rural areas. The results as shown in Table 3 indicated that the predictor variables (relative advantage, compatibility, complexity, trialability, awareness and security) in this study accounted for at least $61.6 \%$ of the variance of Internet banking adoption (adjusted $R$-squared $=0.616$ ). The result further showed trialability and awareness as the main predictor of Internet banking, followed by security and compatibility, respectively. Relative advantage and complexity were found not to be significant predictors of Internet banking adoption in South African rural areas. The regression model was also observed to be significant $($ sig $<0.000)$ and could be used reliably to make conclusions and recommendations for the banks in line with Internet banking adoption.

\section{Conclusions and recommendations Hypothesis testing}

Six hypotheses were formulated for this research and linear regression analysis was used to test these hypotheses by regressing each of the independent variables against the adoption of dependent variables. The finding of this study as indicated in Table 4 shows that the intention to adopt Internet banking services can be predicted by awareness, compatibility, trialability and security, but not by relative advantage and complexity.

\section{Conclusions in relation to the research problem}

The research problem which this study sought to find answers to was the following: Why are South Africans in rural areas are not adopting and using Internet banking despite the availability of Internet banking infrastructure and the effort of banks in promoting Internet banking awareness, security and the convenience of the system? The overall conclusions of this study based on the findings presented in the previous sections are summarised below.

The demographic factors such as age, education, occupation and the level of income have an effect on the adoption of Internet banking in rural areas. The factors such as perceived compatibility, perceived trialability and external variables (awareness and security) were found to 
TABLE 3: Results of regression analysis model in the study.

\begin{tabular}{|c|c|c|c|c|c|c|}
\hline \multirow[t]{2}{*}{ Model } & \multicolumn{2}{|c|}{$\begin{array}{l}\text { Unstandardised } \\
\text { coefficients }\end{array}$} & \multirow{2}{*}{$\begin{array}{l}\text { Unstandardised coefficients } \\
\frac{\text { Beta }}{}\end{array}$} & \multirow[t]{2}{*}{$T$} & \multirow[t]{2}{*}{ Sig } & \multirow{2}{*}{$\begin{array}{l}\text { Dependent variable: } \\
\text { intention of adoption } \\
\text { of Internet banking }\end{array}$} \\
\hline & B & Std. error & & & & \\
\hline (Constant) & -1.683 & 0.652 & - & -2.582 & 0.011 & - \\
\hline Relative advantage & 0.145 & 0.106 & 0.134 & 1.364 & 0.175 & - \\
\hline Compatibility & 0.177 & 0.085 & 0.208 & 2.081 & 0.039 & - \\
\hline Complexity & -0.130 & 0.090 & -0.110 & -1.446 & 0.150 & - \\
\hline Trialability & 0.419 & 0.086 & 0.350 & 4.854 & 0.000 & - \\
\hline Awareness & 0.247 & 0.071 & 0.220 & 3.449 & 0.001 & - \\
\hline Security & 0.284 & 0.107 & 0.168 & 2.650 & 0.009 & - \\
\hline R-squared & - & - & - & - & - & 0.631 \\
\hline Adjusted R-squared & - & - & - & - & - & 0.616 \\
\hline F. Change & - & - & - & - & - & 43.540 \\
\hline Sig & - & - & - & - & - & 0.000 \\
\hline
\end{tabular}

Source: Ramavhona, T.C. \& Mokwena, S.N., 2014, Factors influencing internet banking adoption in South African rural areas, Master's dissertation, Tshwane University of Technology, Tshwane, viewed 09 November 2016, from http://encore.tut.ac.za/iii/cpro/DigitalltemViewPage.external?lang=eng\&sp=1001585\&sp=T\&suite=def

$\mathrm{T}$, this t-test compares the value of the $\mathrm{Y}$-intercept with 0 . If it is significant, then it means that the value of the $\mathrm{Y}$-intercept is significantly different from 0 ; Sig, Significance; $\mathrm{B}$, this is the unstandardized regression coefficient (B); Std. Error, standard error of the mean, also called the standard deviation of the mean, is a method used to estimate the standard deviation of a sampling distribution; R-Squared, R-squared is the fraction by which the variance of the errors is less than the variance of the dependent variable; $F$. Change, A significant ' $F$ Change' value means that there has been a significant improvement in model fit.

TABLE 4: Hypothesis acceptance and rejection test remarks.

\begin{tabular}{|c|c|c|c|c|}
\hline Hypothesis & Variable & Beta & $p$ & Remarks \\
\hline 1 & Awareness & 0.220 & 0.001 & Supported \\
\hline 2 & Relative advantage & 0.134 & 0.175 & Not supported \\
\hline 3 & Compatibility & 0.208 & 0.039 & Supported \\
\hline 4 & Complexity & -0.110 & 0.150 & Not supported \\
\hline 5 & Trialability & 0.350 & 0.000 & Supported \\
\hline 6 & Security & 0.168 & 0.009 & Supported \\
\hline
\end{tabular}

Source: Ramavhona, T.C. \& Mokwena, S.N., 2014, Factors influencing internet banking adoption in South African rural areas, Master's dissertation, Tshwane University of Technology, Tshwane, viewed 09 November 2016, from http://encore.tut.ac.za/iii/cpro/DigitalltemViewPage.external?lang=eng\&sp=1001585\&sp=T\&suite=def

have significant influence on the adoption of Internet banking in South African rural areas. However, relative advantage and complexity were found not to be significant factors influencing the adoption of Internet banking in South African rural areas. It has been found that the majority of respondents from South African rural areas have never used Internet banking, due to customers' lack of resources such as computers with Internet access and costs. Security and the complexity of Internet banking was revealed as one of the factors hampering the intention to adopt Internet banking in South African rural areas because the bank customers perceived Internet banking as unsafe, that the banks offering Internet banking have not yet set enough security measures to protect customers and that Internet banking is difficult to use and not user-friendly.

\section{Acknowledgements Competing interests}

The authors declare that they have no financial or personal relationships which may have inappropriately influenced them in writing this article.

\section{Authors' contributions}

T.R. was the main author of this article and conducted most of the research in regard to the article, while S.M. was the coauthor of this article, performing most of the supervisory role on the article.

\section{References}

ABSA Bank, 2011, Absa electronic banking brochure. ABSA Bank.

ABSA Online, 2015, ABSA online Internet banking/the way internet banking meant to be, viewed 30 January 2015, from http://www.absa.co.za/Absacoza/Individual/ Ways-to-Bank/Anytime,-Anywhere/Absa-Online

Adapa, S., 2011, 'Continued and frequent use of Internet banking by Australian consumers: Identification of the factor components', Journal of Internet Banking and Commerce 16(2), 1-22.

AFDB, 2010, 'Africa Economic Brief', African Development Bank 1(8), 1-16, viewed 29 Nov. 2016, from http://www.afdb.org/fileadmin/uploads/afdb/Documents/ Publications/John\%20brief\%201_John\%20brief\%201.pdf

Agarwal, R. \& Prasad, J., 1998, 'A conceptual and operational definition of personal innovativeness in the domain of information technology', Information Systems Research 9, 204-224. http://dx.doi.org/10.1287/isre.9.2.204

Alsajjan, B. \& Dennis, C., 2009, 'Internet banking acceptance model: Cross-market examination', Journal of Business Research 5(5), 257-272.

April, A.K. \& Cradock, J., 2000, E-business - Redefining the corporate landscape, Butterworths, Durban.

Bareczal, G. \& Ellen, P., 1997, 'Developing typologies of consumer motives for use of technologically base banking services', Journal of Business Research 38, 131-139. http://dx.doi.org/10.1016/S0148-2963(96)00032-X

Brogdon, C., 1999, Banking and the Internet: Past, present, and possibility, viewed 23 April 2011, from http://www-db.stanford.edu.html

Cloete, E. \& Ramburn, H., 2006, 'Determinants of Internet banking: Consumers' versus banks perspective', in Proceedings of the 8th Annual Conference on World Wide Web Applications, Bloemfontein, South Africa, 06-08 September.

Daniel, E., 1999, 'Provision of electronic banking in the UK and the Republic of Ireland', The International Journal of Bank Marketing 17(2), 72-83. http://dx.doi. org/10.1108/02652329910258934

First National Bank (FNB), 2011a, Online banking, viewed 15 July 2011, from https:// www.fnb.co.za/channel/online-banking.html

First National Bank (FNB), 2011b, One time pin (OTP), viewed 18 October 2011, from https://www.online.fnb.co.za/rhelp0/zob/security/one_time_pin.htm

Gerrard, P. \& Cunningham, J.B., 2003, 'The diffusion of internet banking among Singapore consumers', The International Journal of Banking Marketing, viewed 25 April 2013, from http://www.proquest.umi.com/pqdweb?index

Green, S. \& Van Belle, J.P., 2002, Customer expectations of internet banking in South Africa, viewed 2 February 2012, from http://www.commerce.uct.ac.za/ informationsystems/staff/personalpages/jvbelle/pubs/f-VanBelleJeanPaul2.pdf

Gonzalez, M.E., Dentiste, M.R. \& Rhonda, M.W., 2008, 'An alternative approach in service quality: An e-banking case study', The Quality Management Journal 15(1), 41. 
Gounaris, S. \& Koritos, C., 2008, 'Investigating the drivers of internet banking adoption decision', International Journal of Bank Marketing 26(5), 282-304. http://dx.doi. org/10.1108/02652320810894370

Hernandez, J. \& Mazzon, J., 2007, 'Adoption of internet banking: Proposition and implementation of an integrated methodology approach', Marketing 25(2), 72-88.

ITU, 2013, World in 2013 ICT facts and figures, viewed, from http://www.itu.int/en/ ITU-D/Statistics/Documents/facts/ICTFactsFigures2013-e.pdf

Kalakota, R. \& Whinston, A., 1997, Electronic commerce: A manager's guide, Addison Wesley, Reading, MA.

Karjaluoto, H., 2002, 'Selection criteria for a mode of bill payment: Empirical investigation among Finnish Bank customers', International Journal of Retail and Distribution Management 30(6), 331-339. http://dx.doi.org/10.1108/09590 550210429540

Kgantsi, M. \& Mokoene, S., 1997, 'South African farmer support services: An end-use perspective', unpublished research report, Development Bank of Southern Africa.

Kolodinsky, J., Hogarth, J. \& Hilgert, M., 2004, 'The adoption of electronic banking technologies by US consumers', Marketing 22(4), 238-259. http://dx.doi.org/10. $1108 / 02652320410542536$

Kyobutungi, A., 2014, Internet banking and customer satisfaction of commercial banks in Uganda: A case study of Centenary Rural Development Bank in Mbarara municipality viewed from http://www.academia.edu/7388611/internet banking_and_customer_satisfaction_of_commerical_banks_in_uganda_a_case_study_of_centenary_rural_development_bankin_mbarara_municipality

Leow, H.B., 1999, 'New distribution channels in banking services', Bankers Journal Malaysia 110, 48-56.

Loudon, D. \& DellaBitta, A., 1993, Consumer behavior, McGraw Hill, Singapore.

Malhotra, N., 1999, Marketing research: An applied orientation, Prentice Hall, Upper Saddle River, NJ.

Martins, A., Martins, N. \& Olivier, M.S., 2001, 'Consumer perception of electroniccommerce', South African Computer Journal 27, 27-33.

Masocha, R., Chiliya, N. \& Zindiye, S., 2010, E-banking adoption by customers in the rural milieus of South Africa: A case of Alice, Eastern Cape, South Africa.

Mokwena, S.N., 2011, 'Factors influencing the acceptance and use of a school administration and management system in South African high schools', Unpublished PhD thesis, Tshwane University of Technology, Pretoria.

Moore, G.C. \& Benbasat, I., 1991, 'Development of an instrument to measure the perceptions of adopting an information technology innovation', Information Systems Research 2(3), 192-222.

Munusamy, J., 2012, 'Perceived barriers of innovative banking among Malaysian retail banking customers', Journal of Internet Banking and Commerce 17(1), $1-15$.

Onay, C. \& Ozsoz, E., 2013, 'The impact of Internet-banking on brick and mortar branches: The case of turkey', Journal of Financial Services Research 44(2), 187-204. http://dx.doi.org/10.1007/s10693-011-0124-9

O'Connell, B., 1996, 'Australian banking on the Internet - Fact or fiction?', The Australian Banker 110(6), 212-214.

Ongkasuwan, M. \& Tantichattanon, W., 2002, 'A comparative study of Internet banking in Thailand', paper presented at The First National Conference on Electronic Business, Bangkok, 24-25th October.
Pather, P., 2007, The way business is moving, viewed 24 December 2011, from www. Netdotwork.co.za/news/aspx?pklnewsid $=26579$

Peterson, M., 2006, A brief history of internet banking, Ezine Articles, viewed 14 February 2011, from http://ezinearticles.com

Polatoglu, V.N. \& Ekin, S., 2001, 'An Empirical Investigation of the Turkish Consumers' Acceptance of Internet Banking Services', International Journal of Bank Marketing 19(4), 156-161.

Ramavhona, T.C. \& Mokwena, S.N., 2014, Factors influencing internet banking adoption in South African rural areas, Master's dissertation, Tshwane University of Technology, Tshwane, viewed 09 November 2016, from http://encore.tut.ac.za/iii/ cpro/DigitalltemViewPage.external?lang=eng\&sp=1001585\&sp=T\&suite=def

Redlinghuis, A. \& Rensleigh, C., 2010, 'Customer perceptions on Internet banking information protection', South African Journal of Information Management 12(1), 1-6.

Rogers, E.M., 1983, Diffusion of innovations, 3rd edn., Free Press, New York.

Rogers, E.M., 1995, Diffusion of innovations, 4th edn., Free Press, New York.

Rogers, E.M. \& Shoemaker, F.F., 1971, Communications of innovations: A cross-cultural approach, Free Press, New York.

Sathye, M., 1999, 'Adoption of internet banking by Australian consumers: An empirical investigation', International Journal of Bank Marketing 17(7), 324-334. http:// dx.doi.org/10.1108/02652329910305689

Sayar, C. \& Wolfe, S., 2007, 'Internet banking market performance: Turkey versus the UK', International Journal of Bank Marketing 25(3), 122-141. http://dx.doi. org/10.1108/02652320710739841

Statistics South Africa, 2011, Census 2011: Community profiles, Stats SA, Pretoria.

Sohail, M.S. \& Shanmugham, B., 2003, 'E-banking and customer preferences in Malaysia: An empirical investigation', Information Sciences 150, 207-217. http:// dx.doi.org/10.1016/S0020-0255(02)00378-X

Singh, A., 2004, 'Trend in South African Internet banking', Aslib Proceedings, 56(3), 187-196.

Suh, B. \& Han, I., 2002, 'Effect of trust on customer acceptance of Internet banking', Electronic Commerce Research and Applications 1(2002), 247-263.

Taylor, S. \& Todd, P., 1995, 'Understanding information technology usage: A test of competing models', Information Systems Research 6(2), 144-176.

Tan, M. \& Teo, T.S.H., 2000, 'Factors influencing the adoption of Internet banking', Journal of the Association for Information Systems 1(5), 22-38.

Wang, Y., Wang, Y., Lin, H. \& Tang, T., 2003, 'Determinants of user acceptance of Internet banking: An empirical study', International Journal of Bank Marketing 14(5), 501-519, viewed 14 February 2011, from http://ijmbr.srbiau.ac.ir/pdf_64_ f2e1cffc35d055294267fe8a6e1fa0f9.html

Wallis Report, 1997, The financial system inquiry final report, AGPS, Canberra.

Wu, J., 2005, Factors that influence the adoption of Internet banking by South Africans in the EThekwini metropolitan region, viewed 24 December 2011, from http://ir. dut.ac.za/bitstream/handle/10321/114/Wu_2005.pdf?sequence $=13$

Yuan, X., Lee, H.S. \& Kim, S.Y., 2010, 'Present and future of internet banking in China', Journal of Internet Banking and Commerce 15(1), 1-10.

Zheng, L.N., 2010, An empirical analysis of factors that influence the adoption of internet banking in China: A case study of Zhengzhou, viewed from https:// researcharchive.lincoln.ac.nz/bitstream/10182/2633/3/Zheng_MCM.pdf 